\title{
2. Platforms and exploitation in informational capitalism
}

\section{Mariano Zukerfeld}

\section{INTRODUCTION}

Platforms are increasingly shaping work and labour relations all over the world. Various insightful analyses of this apparent tendency have been published, and most of them mention the exploitative nature of these relations. However, they tend to leave aside what kinds of exploitation exist and how they are related to different types of platforms and, more generally, to the present stage of capitalism. Thus, regarding this issue, there are three connected vacancies.

First and foremost, a theory of capitalist exploitation that is capable of (but not limited to) framing the variety of exploitative relations that take place between capitalist platforms and exploited subjects, whether they are workers or not. Exploitation became a ticklish subject for many progressives and left-wing academics, as informational capitalism brought some anomalies to textbook Marxism. Marxist theory of exploitation focuses on waged, 'productive' labour and depends ultimately on time as a universal measure. Now, how to frame relations in which capital obtains a surplus value at the expense of exploited actors, but which do not occur in the context of labour relations? 'Prosumers' on Internet platforms are a typical example: they produce content (software, audiovisuals, texts), data, and pay attention to advertising, etc., but they are not, prima facie, "productive" workers who are capable of producing surplus value according to standard Marxism. Furthermore, how to conceptualize the production processes in which the creation of wealth is not directly related to the notion of working time? This is what happens with the so-called 'knowledge-intensive activities', in which once the knowledge has been created in a certain amount of time, its subsequent uses become dissociated from that initial time amount. Production and reproduction divorce, and this has even more pronounced consequences regarding the production of informational goods, made of digital information and, therefore, having close to zero marginal or reproduction costs. 
This situation has led to two alternatives. On the one hand, the most frequent one among critical scholars consists in resorting only occasionally and vaguely to the notion of exploitation. Their critical vocation is exercised upon other relevant topics as surveillance, precarization, or inequalities instead.

On the other hand, there are scholars who will not give up either Marxism or its concept of exploitation. Among them, the usual responses consist of treating the anomalies that informational capitalism brings up with old Marxist recipes. In turn, it results in two equally unsatisfying options: while some academics try to silence the anomalies by constraining them into the Procrustean bed of a rigid ahistorical theory, others end up forcing Marxist theory with painful contortions to tackle informational capitalism.

It is within this context that this chapter aims to briefly present a theory of exploitation which is capable of dealing with different kinds of exploitation that take place in informational capitalism and particularly in capitalist platforms.

Secondly, platformization is rarely framed by a narrative that clearly distinguishes stages of capitalism and periods within these stages. But even if stages and periods are distinguished, this is usually done by resorting to technological or economic determinisms. However, platform work and especially capitalist exploitation are inextricably related to other traits of informational capitalism.

Thirdly, although sound typologies have been developed on the relation among capitalist platforms, work, and labour, they have been usually focused on a particular subset of platforms, i.e. platforms where the activities carried out by workers easily accommodate to the traditional notion of work. Nonetheless, other platforms where neglected or contested forms of exploitation are emerging are barely looked upon as such.

Therefore, the main objective of this chapter is to relate different types of platforms with different kinds of capitalist exploitation within informational capitalism. In order to reach this goal, we need first to discuss each concept separately and only then put the pieces of the puzzle together.

The second section characterizes the transition from industrial capitalism to informational or cognitive capitalism. Although it is indisputable that digital technologies and the Internet played a major role in that transition, other aspects must be discussed as well. Transformations in the organization of productive processes, regulations (particularly in property law) and business models are obviously crucial and would allow me to distinguish two phases within informational capitalism. But also shifts in axiological beliefs and identities are linchpins of platforms' exploitative side.

The third section is devoted to exploitation. Drawing on a cognitive materialist approach where capitalist exploitation depends ultimately on unremunerated knowledge, it begins by recuperating contributions of previous theories of capitalist exploitation. Then it moves towards providing a defi- 
nition of capitalist exploitation and presenting three kinds that are crucial to give an account of platform work: exploitation through alienation, exploitation through reproduction, and exploitation through attention. Finally, these three kinds of exploitation are related to different business models of industrial and informational capitalism, and to the phases of the latter.

The fourth section discusses what types of work, labour, and productive activities are subsumed under capitalist platforms. On the one hand, there are three types of through-the-platform workers: gig labour, prosumers, and self-employed owners. Gig labour is epitomized by those who work through Uber, Freelancer, Zolvers, and other platforms. The platformization of prosumption brings into tension the distinction between working time and leisure time, and even the traditional concept of work itself. Those who produce and consume content, data, and attention through YouTube or Facebook embody this tendency. In turn, there is commercial work carried out by self-employed owners through platforms (the renting and selling of physical goods) which arguably configures new tendencies in work processes, such as those of Airbnb or Amazon. On the other hand, there are several types of work behind the platforms: in-house or outsourced development of software and hardware, infrastructure, human resources, marketing, logistics, and warehouse work. The fifth section builds on previous sections to present a typology of exploitation of platform work in informational capitalism. Thus, I discuss which of the three types of exploitation proposed in section 3 prevails in each kind of productive activity. Additionally, some comments regarding ideology, ownership of means of production, and the relation between time and value are introduced. The sixth section provides concluding remarks.

\section{INFORMATIONAL CAPITALISM AND ITS DISTINCTIVE FEATURES ${ }^{1}$}

Capitalism can be analytically divided into three stages: mercantile capitalism, which ranges approximately from the mid-15th century to the end of the 18th century; industrial capitalism, which covers the period from the end of the 18 th century up to the third quarter of the 20th century, and informational capitalism, whose beginnings can be approximately dated to the 1970 s and which continues to this day (Castells 1996; Boutang 2011; Zukerfeld 2017). Platforms and platformization of work, as we shall see, are archetypical from the present phase of informational capitalism. But how can we characterize this stage? We aim to answer this question below as briefly as possible while avoiding reductionisms. 


\subsection{Digital Technology and Informational Goods}

Industrial capitalism's most apparent aspect is the development of energy technologies in the form of machines. Informational capitalism, in turn, is strongly associated with information and specifically digital technologies (Castells 1996; Vercellone 2011; Boutang 2011; Fuchs 2010). Understanding its technological underpinnings thus becomes a necessary but not sufficient condition to grasp informational capitalism. Four of these technological underpinnings are summarized below.

Although information technology has existed at least since the origins of writing, informational capitalism is characterized by the fact that digital technologies tend to subsume most information technologies (i.e. analogue information technologies). This advance is due to the particular evolution of productive forces in the branch of hardware production, described by the self-fulfilling prophecy known as Moore's Law. It refers to the exponential progress and cost reduction of the most varied types of digital technologies.

Digital information can be defined as all forms of knowledge codified in binary form through on-off electrical signals. A distinctive feature of digital information is that it has marginal production costs close to zero or, in other words, negligible reproduction costs (Varian 1995; Cafassi 1998; Boutang 2011; Rullani 2000). We refer to all goods composed purely or mainly of digital information as informational goods (software, music, videos, texts, data, etc.). Software is an especially significant type of informational good. It is the most important means of production of our era, as it is a necessary ingredient in all digital technologies.

Informational capitalism is usually characterized as a networked society (Castells 1996). Network properties usually include: high flexibility, the lack of a central node, and the so-called Metcalfe Law: the usefulness of a network increases exponentially with the number of connected nodes. Of course, the relevance of networks in informational capitalism is firmly tied to the boom of networks of digital technologies, the Internet being the main one.

The consumption of superabundant information requires human attention, which is finite and scarce, in order to be meaningful, for humans as well as capitalist enterprise. This divergence between superabundant information and scarce human attention is the material basis that explains why attention has become such a particularly important commodity today (Davenport and Prusack 2001; Simon 1996; Celis Bueno 2016). Despite the fact that the scarcity of attention was important along informational capitalism, it became particularly poignant in its later phase, with the proliferation of broadband and streaming. It is no mystery that the platform economy is built on all of these features. 


\subsection{Organization of Productive Processes}

Informational capitalism radically departs from industrial capitalism regarding the organization of productive processes. Although this transformation is boosted by the technological tendencies mentioned above, it is not in any way determined by them. Organizational features of informational capitalism might be summarized around three interdependent axes: networks, flexibilization, and polarization.

Along with digital networks, two types of well-known but rarely coupled together organizational networks shaped productive processes during the take-off of informational capitalism. On the one hand, the well-known network enterprise, in their interior and exterior: the company as a group of islands, projects articulated in a relatively flexible way, the company as a network reaching towards the exterior, outsourcing anything that exceeds its core business (Castells 1996). In this organizational modality power tends to be exercised as control (complementing or replacing the discipline of the industrial period). On the other hand, collaborative production (production of informational goods among peers over the Internet, usually during free time).

Networks are related to the bunch of organizational trends grouped under the concept of flexibilization. Indeed, it stems from just-in-time, and other organizational features of Toyotism (Coriat 1990; Piore and Sabel 1984), and also from the deregulation of markets championed by neoliberal governments (which are the archetypical political form of informational capitalism). Flexibilization typically includes higher labour turnover, outsourcing and homeworking, unpredictable working hours, variable and individualized wages, the erosion of collective labour, and the relocalization of the production process (Eyck 2003; Standing 2002), all of which tend to result in a precarization of work (Armano and Murgia 2014). Flexibilization is also related to the blurring of the boundary between leisure time and working hours (originally pointed out by Italian Autonomism - e.g. Lazzaratto and Negri 2001), which is boosted by digital technology.

In turn, capitalist metabolism includes a trend towards an increase in the polarization of the workforce. The decomposition of industrial labour results in a split: while some become highly skilled global informational workers, others end up as low-skilled, local, precarious services providers. Not only are these groups linked by their origins, but it is their current dynamics which ties them together. Indeed, informational productive processes in some developed countries depend on legal or illegal precarious labour (Iñigo Carrera 2003; Fuchs and Sevignani 2013).

The platformization of work relies on the aforementioned tendencies. However, platforms add a specific organizational layer which is not in-built in network organizations: they operate as gatekeepers and middle-men, per- 
verting the allegedly horizontal and immanent flow of goods and services that characterize networks. More importantly, the governance of the productive process is increasingly performed by algorithms, i.e. algorithmic management. As a consequence, the so-called platform economy represents a new organizational form that signals the beginning of a second phase within informational capitalism.

\subsection{Subjectification, Recognition and Axiology}

Informational capitalism also means profound changes vis-à-vis industrial capitalism in the way subjects perceive themselves and bond with others; that is, in their identity, subjectification, and recognition (Ricoeur 2005). While in industrial capitalism subjects were built as individuals interacting with a society, in the first phase of informational capitalism, the society as a totality began to fall apart, turning into ever-changing networks. Disaffiliated and vulnerable subjects became more individualistic (Castel 2002). In the second phase, individuals tend to become dividuals (as announced by Deleuze 1992), attention-seeking nodes defined by fragile connections to digital networks.

As opposed to individuals and societies, dividuals and networks are increasingly dependent on capitalist social networking platforms. Thus, and remarkably, identity, subjectivity, and recognition are subsumed under the commercial objectives of those companies.

Regarding the topic of this chapter, the main axiological trait of informational capitalism is the ideology of the entrepreneur of the self (Foucault 2010; Boltanski and Chiapello 2005). From the first decade of the new millennium, that is to say the second phase of the current stage, 'communities' are cheered and, moreover, openness moves from the margins to the centre of capitalist axiology.

\subsection{Regulations and Business Models}

In the transition from industrial to informational capitalism, the capitalist system needed to deal with a very concrete menace: informational goods could escape the commodity form as they had close to zero marginal costs. The first, adaptive, and still extremely relevant attempt of the capitalist system to deal with informational goods was to dramatically expand intellectual property rights (May and Sell 2006; Drahos 2004; Zukerfeld 2017b). This is how a profit-from-enclosures model was deployed, with firms such as Microsoft, Pfizer, and Universal as its flagships.

However, this model increasingly revealed its limits and in the first decade of the new millennium it became clear that it was simply not good enough for capitalist business to prosper. Profit from enclosures is hardly compatible 
with the technological (once the informational good is distributed, it is very difficult to stop its massive circulation) as well as organizational, subjective, and axiological (which favour openness and free flows of informational goods) features of informational capitalism. Indeed, two complementary business models emerged.

As a reaction to the expansion of private intellectual property rights, a movement advocating for open knowledge, free culture, and non-commercial sharing practices spread and thrived (Benkler 2006; Bauwens 2006). At some point in the 2000s, companies started noticing that they might profit from openness and sharing practices: millions of people were willing to work for free. Profit from openness is based on the disguised exploitation of unpaid digital work, carried out mostly during leisure time, with non-commercial purposes, by individuals as part of fan cultures, peer communities, or in the role of being users of some service or platform (Fuchs 2013; Scholz 2013; Fisher 2012; Zukerfeld 2014; Lund and Zukerfeld 2020).

But yet another business model was developed to fight back against the perceived menaces of de-commodification brought by informational capitalism. As informational goods could not be delivered as goods - because illegal copies cannot be controlled - some companies simply decided to provide them as services. Indeed, you do not download the audiovisual content, it is streamed by the platforms instead.

Now we can summarize the division of informational capitalism into two periods. The first one might be called the phase of networks; it lasts from the 1970 s to the 2000 s, and is characterized chiefly by the profit-from-enclosures model - backed by intellectual property rights expansion - the take-off of digital technologies and the Internet, and the slow decomposition of the cultural, political, and philosophical structures that shaped industrial capitalism. The second one, the phase of platforms, extends from the 2000s to the present, and it is dominated by profit from openness and informational goods as services business models, the organizational, axiological, identity features described above, which are all related to the ubiquitous presence of Internet platforms and their algorithms. ${ }^{2}$

Bearing this in mind, we can associate concepts such as the post-industrial society (Bell 1973) or societies of control (Deleuze 1992) with the first period of informational capitalism. Even narratives by Castells (1996) or cognitive capitalism theorists (Rullani 2000; Boutang 2011; Vercellone 2011) tend to be focused on the features of this first period. At the other end of the spectrum, concepts such as platform capitalism (Srnicek 2017) and surveillance capitalism (Zuboff 2019) place their emphasis on the second period of informational capitalism. 
Here I want to briefly introduce a theory of exploitation which draws on the contributions of various authors. On the one hand, a Marxian approach (Marx [1867] 1990, but also Hilferding [1910] 1981; Sweezy 1942), from which I maintain the necessity of exploitation, understood as a relationship of free and legal exchange of objectively asymmetrical magnitudes, to all stages of capitalism. On the other hand, Sraffian (Hodgson 1988; Garegnani 1979) and Analytic Marxist approaches (Roemer 1985; Cohen 1979; Elster 1985; Wright 1985) contributed to keep the emphasis on a theory of exploitation that is not necessarily based on Marx's labour theory of value. Also, they provided me with the vocation for systematic analysis. However, this perspective has not incorporated elements which help us to consider the exploitation that occurs in informational capitalism. Similarly, authors from autonomist and cognitive capitalism currents have touched on the subject (Fumagalli 2015; but especially Boutang 2011). From these and other authors I take the idea of the divorce between labour time and value production and the integration of intellectual property into the analysis. However, I reject the autonomist philosophical perspective and respectfully disagree with some traits of cognitive capitalism theory (for instance, its subsumption of knowledge to labour). Finally, from cultural materialism and associated perspectives (Fuchs 2010, 2012, 2015; Fisher 2012), the main contributions that I appropriate are, on the one hand, the idea that online platforms, in contrast to discourses about freedom and community, operate on the basis of the capitalist exploitation of users (although not only of them), and, on the other hand, the updating of Smythe's (2006) contribution which conceives of a type of exploitation of audiences through social media sites.

In this context, here I will concisely define capitalist exploitation and its three modalities. I understand capitalist exploitation to be a social relationship that fulfils the following requirements:

1. Exchanges inscribed into productive processes are generated between at least two classes of actors, Exploiters $(E)$ - who receive or translate resources - and exploited (e) - who produce or bear them.

2. The exchanges between $E$ and $e$ are, in economic terms, objectively asymmetrical in relation to the value of the goods and services transacted, in such a way that $E$ obtains a surplus value as regards $e .^{4}$ This occurs regardless of the subjective representations that these actors hold about said exchanges. ${ }^{5}$

3. The productive processes in question are orientated to the production of commodities. Specifically, the $E$ actors involved in these processes act 
(including in relation to the $e$ actors) with the principal - if not the exclusive - goal of making a profit.

4. The positions of $E$ and $e$ are also asymmetrical with regard to the perspective that they have about the productive process which they share: while the $E$ actors tend to have an overarching view of the totality of the process, the $e$ actors only perceive one or a few fragments of the process.

5. These relationships take place, to a greater or lesser degree, in a consensual way and are not illegal: they do not imply any clear, evident, or indisputable violation of any current legislation.

\section{Capitalist exploitation adopts three modalities:}

\section{Exploitation through alienation}

This modality is the closest to the traditional Marxian concept of exploitation. It is characterized by the purchase, by capital, of a certain amount of working time; that is, the exclusive use of human energy and knowledge through its application to the object of work over a given period. This working time can be fixed or flexible, long or short, it does not matter at this point. Usually, the capitalist contributes the means of production while the goods and services produced by labour are by definition owned by the capitalist, all under the laws of physical private property. Thus, energies and knowledge are objectified in the goods (or consumed in the services provided) but, decisively, the product of the labour performed by the exploited turns out to be alienated from the worker. The capitalist realizes it as a commodity through its sale, obtaining the pursued surplus value. Nonetheless, to put the productive process into motion again, the exploiter must resort to labour power again and again.

This modality works very well to understand and measure exploitation where the application of productive knowledge (which generates value) tends to coincide with working time: energy-intensive tasks and/or those in which the knowledge used is relatively stable in time. This was the usual case during industrial capitalism and that is why this modality is characteristic of that period, although it remains in the present.

\section{Exploitation through reproduction or copying}

Exploitation through reproduction or copying refers to the situation in which the exploiters reproduce knowledge that had been created or was carried out by the exploited, usually by translating it into a new bearer. This knowledge becomes the property of the capitalist exploiter, due to the lines drawn by intellectual property law (patents, copyright, trademarks, and others).

Capital may proceed to the objectification of said knowledge in machinery (industrial or informational), its codification in manuals of procedures, or its inoculation into other workers. 
Thus, even if the exploited continues to possess said knowledge materially, she might be dismissed and, in some cases, even banned from using the knowledge she stills carries.

Exploitation through reproduction encompasses various sub-modalities. Here it suffices to say that it can occur both inside and outside labour processes.

\section{Exploitation through attention}

In exploitation through attention, certain digital information is inoculated by the exploiting actors into the subjectivity of the exploited actors. This modality is based on the aforementioned fact that in the second phase of informational capitalism the flood of information results in scarcity of human attention. Thus, scarce human attention - whose consumption exhausts it - is exchanged for superabundant access to informational goods whose cost of reproduction tends to zero, shaping potentially asymmetrical exchanges of values.

In the guise of the exploiter actor giving away something, he actually gets something more valuable for free: human attention and the possibility of disembarking his ads and taking advantage of the cognitive, affective, and emotional networks of the exploited actors.

Exploitation through attention is of a different nature than the two previous modalities and is the most alien to the usual notion of exploitation. Of course, its distinctive feature is that the direction of knowledge flows is reversed: capital is looking for introducing knowledge bits into exploited subjects, as it profits from selling the cognitive storage capacity of them. In turn, it takes place mostly in leisure time and the exploited prosumers are external to the firms which profit from them. Furthermore, monetary exchanges are generally not involved in the relationship and, in fact, whether the activities that the exploited carries out might or might not be called 'labour' is a contested topic. In other words, labour is not a sine qua non condition for exploitation to take place. While even the most alienated workers are aware that they participate in a productive process, those exploited through attention perceive themselves as involved just in processes of idle consumption. Again, we come across a key point: here there are capitalist productive processes, and therefore exploitation, but there may be no work for the exploited.

It is crucial to point out that the three modalities are not mutually exclusive, but rather that two or three of them act (sometimes in consort) simultaneously in many productive processes. As mentioned above, an admittedly polemical but crucial tenet of this approach is that exploitation implies the existence of a productive process, but not necessarily a labour process. 
Table 2.1

Types of capitalist exploitation

\begin{tabular}{l|l|l}
\hline Through alienation & $\begin{array}{l}\text { Through reproduction } \\
\text { Capitalist copies knowledge } \\
\text { created by exploited in labour or } \\
\text { leisure time. }\end{array}$ & $\begin{array}{l}\text { Capitalist gets attention time during } \\
\text { exploited leisure time. }\end{array}$ \\
\hline $\begin{array}{l}\text { Energies and knowledge of } \\
\text { the exploited are objectified } \\
\text { and owned by the capitalist } \\
\text { through private physical } \\
\text { property law. }\end{array}$ & $\begin{array}{l}\text { Knowledge is translated into } \\
\text { information that the capitalist owns } \\
\text { through intellectual property law. }\end{array}$ & $\begin{array}{l}\text { Information managed by the } \\
\text { capitalist is translated into } \\
\text { subjective knowledge of the } \\
\text { exploited. }\end{array}$ \\
\hline $\begin{array}{l}\text { Services of the exploited are } \\
\text { required repeatedly. }\end{array}$ & $\begin{array}{l}\text { A particular knowledge-bearer } \\
\text { exploited subject is no longer } \\
\text { needed. }\end{array}$ & $\begin{array}{l}\text { Scarce attention of the exploited is } \\
\text { needed repeatedly. }\end{array}$ \\
\hline $\begin{array}{l}\text { Traditional notion of } \\
\text { exploitation during industrial } \\
\text { capitalism. }\end{array}$ & $\begin{array}{l}\text { Present throughout history, but } \\
\text { widespread in informational } \\
\text { capitalism. }\end{array}$ & $\begin{array}{l}\text { Archetypical of the phase of } \\
\text { the platforms of informational } \\
\text { capitalism. }\end{array}$ \\
\hline
\end{tabular}

Source: Author's elaboration.

How are these types of exploitation related to different stages of capitalism and their distinctive features? Different types of exploitation are indeed related to the various stages of capitalism. However, those connections are not linear and should not be oversimplified. In a nutshell, exploitation through alienation was paramount during industrial capitalism but it is still quite relevant in informational capitalism. In turn, exploitation through reproduction always existed. It soared during industrial capitalism through the codification of workers' knowledge by Taylorist procedures and its objectification in machines. But the features of digital information and informational goods discussed in section 2 boosted exploitation through reproduction to a whole new level. In turn, the aforementioned polarization of the workforce in informational capitalism results in informational workers being mainly exploited by reproduction while precarious services providers tend to be exploited by alienation.

Regarding business models, exploitation through reproduction is easily related to profit from enclosures: companies making money on their knowledge-producing workers, paying once (or extremely modest royalties) and selling thousands of copies. On the other hand, exploitation through reproduction managed to take advantage of profit from openness as well, resorting not to waged workers, but to unwaged prosumers.

Exploitation through attention emerges prominently only towards the end of industrial capitalism, with mass media and broadcasting. But it is only during informational capitalism, and specifically its second phase, where it becomes profoundly relevant to grasp the dynamics of capitalism. This is so not only 
due to the generalization of Internet platforms based on advertising and data gathering, but also because of the subjectification, recognition, and identity traits of informational capitalism and especially those of its second phase: entrepreneurs themselves - who are ultimately dividuals seeking attention - are especially well-suited for being exploited through attention - and reproduction. This is why exploitation through attention is strongly associated with profit-from-openness business models.

\section{PLATFORMIZATION: WORK BEHIND AND THROUGH CAPITALIST PLATFORMS ${ }^{6}$}

Platformization affects all types of work and non-work-related activities. The separation is not clear-cut and there is a great variety of productive modalities which test the validity of the concepts of work and labour proper to industrial capitalism (Srnicek 2017; Scholz 2017; Langley and Leyshon 2017; Madariaga et al. 2019).

Types of platform work are discussed in several studies (De Groen et al. 2016; Howcroft and Bergvall-Kåreborn 2018; Graham and Woodcock 2018; Berg et al. 2018; Schmidt 2017; Vandaele 2018). In what follows I build on these insightful approaches to advance a typology capable of tackling not just work but, more precisely, capitalist exploitative relations, which exceed labour relations, as we shall see.

I provisionally define platform work as the productive activities of those subjects who are directly involved in generating profits for the platforms. Thus, what justifies grouping them together is that they are crucial to figure out how platforms make money. But how to distinguish the main types of platform work? Table 2.2 summarizes my proposal.

Table 2.2 Types of exploited subjects and productive activities in for-profit platforms

\begin{tabular}{l|l|l|l}
\hline $\begin{array}{l}\text { Type of } \\
\text { activities }\end{array}$ & \multicolumn{1}{l}{$\begin{array}{l}\text { Sub-type of } \\
\text { exploited } \\
\text { subjects }\end{array}$} & \multicolumn{1}{l}{$\begin{array}{l}\text { Goods and } \\
\text { Services } \\
\text { produced }\end{array}$} \\
\hline $\begin{array}{l}\text { Behind the } \\
\text { platform }\end{array}$ & $\begin{array}{l}\text { Services' } \\
\text { workers }\end{array}$ & Services & Wamples \\
\cline { 2 - 4 } & $\begin{array}{l}\text { Industrial } \\
\text { workers }\end{array}$ & Physical goods & Hardware builders in Amazon \\
\cline { 2 - 4 } & $\begin{array}{l}\text { Informational } \\
\text { workers }\end{array}$ & $\begin{array}{l}\text { Informational } \\
\text { goods }\end{array}$ & Software developers in Amazon \\
\hline
\end{tabular}




\begin{tabular}{|c|c|c|c|}
\hline $\begin{array}{l}\text { Type of } \\
\text { activities }\end{array}$ & $\begin{array}{l}\text { Sub-type of } \\
\text { exploited } \\
\text { subjects }\end{array}$ & $\begin{array}{l}\text { Goods and } \\
\text { Services } \\
\text { produced }\end{array}$ & Examples \\
\hline \multirow[t]{6}{*}{$\begin{array}{l}\text { Through } \\
\text { the } \\
\text { platform }\end{array}$} & \multirow[t]{2}{*}{$\begin{array}{l}\text { Self-employed } \\
\text { owners }\end{array}$} & $\begin{array}{l}\text { Physical goods } \\
\text { and related } \\
\text { services }\end{array}$ & Airbnb hosts, Amazon sellers \\
\hline & & $\begin{array}{l}\text { Informational } \\
\text { goods }\end{array}$ & $\begin{array}{l}\text { Authors sharing music through Spotify } \\
\text { App developers for Play Store or App Store }\end{array}$ \\
\hline & \multirow[t]{2}{*}{ Gig labour } & Services & $\begin{array}{l}\text { Delivery workers of Deliveroo } \\
\text { Uber drivers } \\
\text { TaskRabbit cleaning workers }\end{array}$ \\
\hline & & $\begin{array}{l}\text { Informational } \\
\text { goods }\end{array}$ & $\begin{array}{l}\text { Software developers, writers, audiovisual content } \\
\text { producers, and microtaskers on Upwork, and } \\
\text { Freelancer } \\
\text { Crowdworkers on Amazon Mechanical Turk }\end{array}$ \\
\hline & \multirow[t]{2}{*}{ Prosumers } & $\begin{array}{l}\text { Informational } \\
\text { goods }\end{array}$ & $\begin{array}{l}\text { Content creators for Facebook or YouTube } \\
\text { Data producers for all platforms }\end{array}$ \\
\hline & & $\begin{array}{l}\text { Attention } \\
\text { services }\end{array}$ & $\begin{array}{l}\text { Audiences paying attention to ads on Facebook or } \\
\text { YouTube }\end{array}$ \\
\hline
\end{tabular}

Source: Author's elaboration.

There are four main types of platform work. The first distinction splits work behind and through the platform. While the latter refers to productive activities that are mediated by the platforms, the former alludes to the production and reproduction process of the platform company and the platform itself. Work through the platforms deserves a closer look and encompasses three varieties: self-employed owners, gig labour, and prosumers.

\subsection{Behind-the-Platform Workers}

Platforms, as productive units, are located in the fourth sector; that is, the information sector of the economy. As we discussed above, they employ informational workers but also industrial and services workers. Informational workers are unavoidable to run and maintain the platform itself: software developers and data scientists, audiovisual content designers, etc. As this is the core business, most of these workers are in-house. Some industrial workers are also needed, for instance to develop hardware. And platforms certainly require service workers, as warehouse and delivery workers. Industrial and services workers are to some extent outsourced.

Platforms are usually depicted as having a meagre workforce. This might be true for some platforms, but it is certainly not the case for others. Take Amazon, which nowadays (March 2020) employs 798,000 behind-the-platform 
workers. What do they do? Some 250,000 workers provide physical services in warehouses ('fulfilment centers' in Amazon jargon), but the rest of them work in a wide array of activities.

Thus, the fact that platform companies typically profit from underpaid 'independent-contractors' and unpaid prosumers should not obscure the fact that thousands of workers are under more or less formalized waged arrangements behind these platforms.

\subsection{Through-the-Platforms Workers}

\section{Self-employed owners}

Self-employed owners refer to platforms on which physical and informational goods are bought, sold, and rented. In this case, it is debatable whether the activities of asset-owners can be described as labour. However, in the case of micro or small businesses it is justified to label those activities as platform work if a certain threshold of production of goods and services is surpassed and their commercial activity entirely depends on Internet platforms.

There are two types of self-employed owners working through platforms. On the one hand, those providing services, renting, or selling physical goods. People selling stuff they produce through commerce platforms but also those who rent their houses through accommodation platforms. On the other hand, those producing informational goods. This includes musicians which upload their recordings to Spotify or similar platforms, or individual (or small firms of) software developers delivering apps through Play Store or App Store.

In this modality, the production of the goods and services - in other words, the productive process prior to their commercialization - takes place outside the platform. Thus, on the surface, it appears as if the platform enabled commerce, instead of production or consumption. However, the very reason why the productive process was set in place is, in reality, platforms. The production of an app or the rental of an apartment was conceived only as part of a platform-governed process. Indeed, small units of capital are increasingly subordinated to the control of platforms, their algorithms, and rankings, beyond specific legal forms.

\section{Gig labour}

Also, in gig labour a fundamental internal division arises from the materiality of the product of labour. Some workers offer physical services (transportation, food delivery, domestic services, and other manual labour), while others mediate the production of informational goods (i.e. software, audiovisual content). The means of production, the applicable regulations, public visibility, and political demands are accordingly divergent. 
To distinguish varieties within the production of informational goods, I would resort to intellectual property and use the threshold of a work (a complete unit upon which copyright is bestowed automatically from its fixation on a tangible medium). While in 'crowdwork' or 'microtasking' workers develop tasks which fail to surpass that threshold, in other 'freelance' activities complete works of authorship are produced.

Physical gig labour is in all likelihood the category which brought public attention to platform work. It might be divided according to the spaces in which they are provided: public (transportation, delivery, and others) and private (cleaning, repairing) (Vandaele 2018). Not only are the platforms which intermediate in these types of labours specialized, but also regulations differ.

\section{Prosumers}

Prosumers perform the now well-known combination of the production and consumption of informational goods, mainly during leisure time and without any necessary monetary compensation. More precisely, there are three types of activities that might (or might not) be referred to as work.

Firstly, content production. For instance, some 50 million YouTubers upload 60 hours of video each minute. To engage prosumers in helping the platform to be profitable, YouTube successfully appeals to fantasies of enrichment, despite 97 per cent of 'creators' not earning enough to surpass the poverty line, payments per view having decreased in comparison to 2015, and the ratio between videos and views being on the fall (Bärtl 2018).

Secondly, prosumers also consume content and, more importantly, ads. Indeed, YouTube has 1.9 billion monthly active users worldwide, who watch some 5 billion videos daily, giving away not only their data, but also their valuable and scarce attention (Omnicore 2019). This has been stressed by Fuchs (2010) and his colleagues (e.g. Fisher 2012) who build on Dallas Smythe's (2006) notion of the audience commodity. According to this perspective, Internet users consuming ads are labouring and, therefore, creating value and being exploited (Fuchs 2010).

Thirdly, prosumers give away all types of data by 'sharing' personal preferences and location, liking videos, ranking drivers, and so forth. The relevance of these seemingly infinitesimal contributions has been underlined repeatedly and, as it was previously said, Srnicek (2017) even defines all capitalist platforms in relation to their profiting from these data. Therefore, prosumption as the main activity carried out on specific platforms (prosumption platforms such as YouTube or Instagram) must be added to the handing over of data that users (becoming prosumers) carry out on every single platform. But does the production of data qualify as work? The extent to which both ads consumption and data generation configure work is a contested topic (for instance Bolaño 
and Vieira, 2015 and Fuchs 2015). Here it is enough to stress that this kind of activity must not be swept under the carpet when exploitation in informational capitalism is discussed.

\section{BEYOND WORK AND LABOUR: EXPLOITATION AND CAPITALIST PLATFORMS}

To discuss exploitation in capitalism platforms' productive processes, it is important to distinguish between capitalist platforms themselves and specific productive activities carried out by different subjects. This allows us to better understand that most capitalist platforms draw on at least two modalities of exploitation, and many of them rely on the three of them. Indeed, there are various kinds of workers and prosumers involved in most platforms' productive processes and each one might be exploited in different ways. Therefore, in the same vein as Table 2.2, Table 2.3 intends not to focus on platforms but on the kinds of productive activities and exploitative relations that subjects are involved in.

\section{Table 2.3 Exploited subjects and type of exploitation}

\begin{tabular}{l|l|l|l}
\hline \multirow{2}{*}{$\begin{array}{l}\text { Type of } \\
\text { activities }\end{array}$} & \multicolumn{1}{l}{$\begin{array}{l}\text { Sub-type of } \\
\text { exploited } \\
\text { subjects }\end{array}$} & \multicolumn{2}{l}{$\begin{array}{l}\text { Goods and services } \\
\text { produced }\end{array}$} \\
\hline \multirow{2}{*}{$\begin{array}{l}\text { Behind the } \\
\text { platform }\end{array}$} & Services workers & Services & Through alienation \\
\cline { 2 - 4 } & $\begin{array}{l}\text { Industrial } \\
\text { workers }\end{array}$ & Physical goods & Through alienation \\
\cline { 2 - 4 } & $\begin{array}{l}\text { Informational } \\
\text { workers }\end{array}$ & Informational goods & Through alienation and reproduction \\
\hline \multirow{2}{*}{\begin{tabular}{l} 
platform \\
\cline { 2 - 4 }
\end{tabular}} & $\begin{array}{l}\text { Self-employed } \\
\text { owners }\end{array}$ & $\begin{array}{l}\text { Physical goods and } \\
\text { Related services }\end{array}$ & Through alienation \\
\cline { 2 - 4 } & Gig labour & Services & Through reproduction \\
\cline { 2 - 4 } & & Informational goods & Through reproduction and alienation \\
\cline { 2 - 4 } & Prosumers & Informational goods & Through reproduction \\
\cline { 2 - 4 } & & Attention services & Through attention \\
\hline
\end{tabular}

Source: Author's elaboration.

Thus, exploitation through alienation takes place mainly regarding service and industrial work behind and through the platforms - and to a lesser extent, to some informational work. This refers to workers whose payment is directly related to working time. Exploitation through reproduction is closely related 
to informational workers and prosumers - who produce informational goods which can be payed once, but copied and sold many times at close to zero marginal costs - but also to the production of massive amounts of data by all the subjects involved in these productive processes. Exploitation through attention, in turn, is largely concentrated in the attention services that audiences of prosumers provide to capitalist platforms.

An important caveat concerns the fact that there is no claim that exploitation necessarily exists in each type of productive activity. Table 2.3 only suggests, in each case, which kind of exploitation would take place if and only if the requisites for exploitative relations discussed in section 3 are met. ${ }^{7}$

As mentioned above, most platforms tend to resort to different kinds of exploitation, as they exploit different kinds of subjects in several productive processes. To illustrate how capitalist platforms take advantage of the different forms of exploitation, we can use again the example of YouTube. ${ }^{8}$ YouTube generated US\$15,150 million revenues in 2019 through its platform developed and supported by some 2,000 waged workers. Monetization is mainly explained by ads displayed on the 5 billion videos uploaded daily by YouTube's 50 million content creators or prosumers, watched by some 1,900 million users (Lund and Zukerfeld 2020, chapter 5).

But where are the revenues ultimately coming from? Marxian orthodoxy would emphasize exploitation of the 2,000 waged employees, this is, exploitation through alienation. The ratio between revenues and employees (known as RPE) is sometimes used as a measure of labour productivity or labour exploitation. In the case of YouTube, the company is making some US\$10 million per employee per year. It turns out to be a colossal figure, not only if compared to McDonald's (US\$66,000), Starbucks (US\$84,000), or Accenture (US\$87,000), but also to Facebook (US\$1.6 million) and Alphabet itself (US\$1.3 million) (Craft, 2017). Therefore, it becomes clear that either YouTube workers are incredibly productive and heavily exploited or there are other sources of value that the company profits from.

So, first of all, it must be distinguished that in addition to the exploitation through alienation of these workers, many of them are exploited through reproduction: they are paid for the development of software that is used repeatedly without additional compensation. But exploitation through reproduction is the key to understanding the contribution of the 50 million prosumers (of which only a tiny fraction receives some income at all, which even for them is quite modest, despite the platform's success in spreading the ideological discourse that 'YouTubers' get rich). These prosumers then give up their content (under the Terms of Service of the platform) that will attract users to the platform and, of course, to consume advertising. Here, then, the third modality is the one that helps to understand how YouTube earns money: the asymmetric exchange between the low commercial value provided by the firm for offering the videos 
and the value of the attention of the users who consume them, that is, the exploitation through attention.

So, YouTube, as many other platform companies, combines different modalities of exploitation of workers, prosumers, and users to shape a complex scheme of capital accumulation.

Exploitation through reproduction and through attention are helpful then not to replace but to complement exploitation through alienation. Indeed, exploitation through reproduction and through attention are especially useful to tackle situations where the production of use values that are crucial for the companies to generate profits are generated outside the factory, the worktime, and waged relations. This approach to exploitation might prove useful to counter discourses regarding topics where many Marxists perspectives fall short.

Capitalist platforms have put together a particular ideological discourse, whose main trait consists in referring to the workers as 'independent contractors' or 'partners', aiming at obscuring labour relations and exploitation (Howcroft and Bergvall-Kåreborn 2018). This could certainly not be detached from the ideological framework of the 'entrepreneur of the self' discussed in section 2 .

In the same vein, ideological discourses from platforms include the so-called 'freedom': despite their differences, most - if not all - workers are said to choose their working hours. Of course, this is but negative freedom which neglects the material needs of workers and the fact that working time is ultimately governed by algorithms.

At the same time, most platforms flag up concepts usually associated with non-commercial spheres: communities (that are in reality instrumental networks), creativity (which YouTube understands as creating and expanding audiences), openness, affectivity, happiness, play, and enjoyment (all of which help to engage unpaid or underpaid producers) (Lund and Zukerfeld 2020, chapter 6).

Noticeably, in most of the through-the-platform work, payments and income are not necessarily measured in terms of labour time but on a piecework-based payment, (Vandaele 2018) or per-click in prosumption. This feature together with outsourcing resembles both the putting-out system and the piecework that Marx described (Marx [1867] 1990, chapter 13-14) and suggests a second 'formal subsumption of labour under capital' as Vercellone (2011) mentioned in another context.

Moreover, in activities performed through the platform, workers and prosumers are owners of the means of production. Although there are huge differences between owning houses, musical instruments, and bikes, all of them alleviate the platforms from providing these means. As mentioned above, in informational capitalism workers' ownership of important means of work 
is not enough for them to stop depending on the capitalist class, as platforms themselves (software, hardware, storage capacity, and, more importantly, attention flows of demand) become the mean means of production and are still controlled by capitalist firms.

Summing up, our approach allows us to focus on exploitation taking place in productive processes, instead of just work or labour. Exploitation might occur framed by work relations, during labour time, and be related with the ownership of the means of work. But, in the phase of platforms within informational capitalism, capitalist exploitation can also be located outside work relations, during leisure time, or, more accurately, in contexts where time and value are not straightforwardly related.

\section{CONCLUDING REMARKS}

In this chapter I have tried to combine a characterization of informational capitalism with a theory of exploitation and a typology of platform work to advance a proposal regarding how productive activities (work and prosumption) taking place on Internet platforms might be exploited by capitalist companies. At this point, it is worth introducing some caution and underlining some characteristics of the proposed approach.

There are two basic stands regarding exploitation. On the one hand, those that deny exploitation. Neoclassical theorists and the like assume that value is subjective and that exchanges in the market are due to the exercise of free will. Therefore, if parties agree on entering into certain relations, that means that the value exchanged in those relations is perceived as convenient for both said parties. Thus, exploitation only takes place in rare and anomalous situations. On the other hand, some Marxist approaches tend to assume that every single exchange under capitalist relations is exploitative. This stems from the confusion between the micro and the macro levels. Capitalism as a whole depends on exploitation (and also expropriation and regulation, by the way) to survive and grow. However, this should not obscure the fact that lots of capitalist businesses fail in their exploitative aims, while others are extremely successful. The former might survive resorting to financial expropriations, rents, and other resources, or simply die. Therefore, to discuss whether exploitation takes place in a particular productive process, empirical evidence would be helpful.

Here we support an approach to exploitation which assumes that value is objective, that freedom does not dissolve exploitation, and that, in order to understand informational capitalism, we need to sublate Marx. Capitalism requires exploitation, but not all exploitation implies work and labour relations. Our approach to exploitation - and specifically to capitalist platforms' exploitation of workers and prosumers - highlights the relevance of different types of knowledge in creating value. Moreover, as we focus on flows instead 
of individuals, it is a non-human-centred approach. This is closely related to one of the striking features of platforms as organizational devices. During industrial capitalism, there was a clear split among production, distribution, and consumption. Exploitation took place in the realm of production, as Marx emphasized. However, in informational capitalism, and particularly in its second phase, the division among production, distribution, and consumption became blurred partially because of the very existence of platforms - though the relation is dialectical, as platforms could only thrive in societies which already had faded away that division.

The key is that platforms, as firms, command productive processes but, at the same time, govern exchanges, and even consumption might take place on them. Platforms internalize markets. As many authors have pointed out, capitalist productive activities have expanded well beyond the traditional limits of production and labour. This is one of the reasons why some forms of exploitation (i.e. through reproduction and through attention) that already existed, but had rarely been noticed during industrial capitalism, became evident.

\section{NOTES}

1. Sections 2 and 4 are based on and summarize findings of a journal article which is currently under evaluation.

2. It is worth noting that the distinction between phases is dialectical - in a Hegelian sense. This implies that the arrival of the second phase does not mean the end or disappearance of the tendencies of the first one, but their sublation (negation, preservation, and up-lift).

3. This section is a summary and re-elaboration of Zukerfeld 2017, chapter 5, which provides an in-depth version.

4. Of course, this does not mean that in all cases gauging the magnitude of this asymmetry is easy or even possible. But the difficulty of numerically measuring something does not imply that it is impossible to grasp, or, still less, that it does not exist.

5. The fact that $e$ actors consider these relationships to be legitimate or even useful does not prevent this characteristic from being present.

6. This section is based on and summarizes a journal article which is currently under evaluation.

7. Of course, we tend to believe that Deliveroo riders are much more likely to be exploited than Airbnb hosts. However, this chapter does not deal with this particular topic, and it would be a mistake to assume that some activities are inherently passible of exploitation where others are not. Special care must be taken regarding the relation between ownership of means of production and exploitation, as we will discuss below.

8. The figures in the main text refer specifically to YouTube (not to Google or Alphabet). For an in-depth discussion of YouTube's business model, see Lund and Zukerfeld 2020, chapter 5. 


\section{REFERENCES}

Armano, E. and Murgia, A. (2014), 'The precariousnesses of young knowledge workers: A subject-oriented approach', Global Discourse, 3 (3-4), 486-501.

Bärtl, Mathias (2018), 'YouTube channels, uploads and views: A statistical analysis of the past 10 years', Convergence: The International Journal of Research into New Media Technologies 2018, 24 (1), 16-32.

Bauwens, M. (2006), 'The political economy of peer production', Post-autistic Economics Review, 37, 33-44.

Benkler, Y. (2006), The Wealth of Networks: How Social Production Transforms Markets and Freedom, Boston, MA: Yale University Press.

Berg, J., Furrer, M., Harmon, E., Rani, U. and Silberman, S. (2018), Digital Labour Platforms and the Future of Work. Towards Decent Work in the Online World. Report. ILO.

Bolaño, C. R. S. and Vieira, E. (2015), 'The political economy of the internet: Social networking sites and a reply to Fuchs', Television \& New Media, 16 (1), 52-61.

Boltanski, Luc and Chiapello, Eve (2005), The New Spirit of Capitalism, London: Verso Press.

Boutang, Y. M. (2011), Cognitive Capitalism, Cambridge: Polity Press.

Cafassi, E. (1998), Bits, moléculas y mercancías. En Finquelievich y Schiavo (comps.) La ciudad y sus TICs: tecnologías de información y comunicación. Buenos Aires: Universidad Nacional de Quilmes.

Castel, R. (2002), From Manual Workers to Wage Laborers: Transformation of the Social Question, New Brunswick, NJ: Transaction.

Castells, M. (1996), The Rise of the Network Society. Vol. I of The Information Age: Economy, Society and Culture, Malden, MA and Oxford: Blackwell.

Celis Bueno, C. (2016), The Attention Economy: Labour, Time and Power in Cognitive Capitalism, London: Rowman \& Littlefield International.

Cohen, G. A. (1979), 'The labor theory of value and the concept of exploitation', Philosophy \& Public Affairs, 8 (4), 338-360.

Coriat, B. (1990), L'Atelier et lê robot: Essai sur lê fordisme et Ia production de masse à l'âge del'électronique, Paris: Christian Bourgeois.

Craft (2017). Retrieved from https://craft.co/reports/s-p-500-revenue-per-employee -perspective

Davenport, T. and Prusak, L. (2001), Conocimiento en acción, Buenos Aires: Pearson Education.

De Groen, W. P., Maselli I. and Fabo B. (2016), 'The digital market for local services: A one night stand for workers? An example from the on-demand economy', CEPS Special Report 133, Brussels, European Centre for Political Studies. https://www.ceps.eu/ publications/digital-market-local-services-one-nigh t-stand-workers-example-demandeconomy

Deleuze, G. (1992). 'Postscript on the societies of control', October, 59 (Winter), 3-7.

Drahos, P. (2004), 'Who owns the knowledge economy? Political organising behind the TRIPS' (Briefing 32), Newton, UK: The Corner House.

Elster, J. (1985), 'Roemer versus Roemer. Un comentario a Nuevas direcciones en la teoría marxiana de la explotación', Mientras Tanto, 22, 115-127.

Eyck, K. (2003), 'Flexibilizing employment: An overview', ILO Working Papers 993597573402676. International Labour Organization. 
Fisher, E. (2012), 'How less alienation creates more exploitation? Audience labour on social network sites', TripleC: Communication, Capitalism \& Critique, 10 (2), 171-183.

Foucault, M. (2010), The Birth of Biopolitics: Lectures at the Collége de France, translated by Graham Burchill, Houndmills: Palgrave Macmillan.

Fuchs, C.(2010), 'Labour in informational capitalism', The Information Society European Journal of Social Theory, 26 (3), 179-196. DOI: 10.1080/01972241003712215.

Fuchs, C. (2012), 'Dallas Smythe today - The audience commodity, the digital labour debate, Marxist political economy and critical theory. Prolegomena to a digital labour theory of value', TripleC: Communication, Capitalism \& Critique, 10 (2), 692-740. http://www.triple-c.at/index.php/tripleC/article/view/443

Fuchs, C. (2013), 'Class and exploitation on the internet', in T. Scholz (ed.), Digital Labor: The Internet as Playground and Factory, New York: Routledge, pp. 211-224.

Fuchs, C. (2015), 'Against divisiveness: Digital workers of the world unite! A rejoinder to César Bolaño and Eloy Vieira', Television \& New Media, 16 (1), 62-71.

Fuchs, C. and Sevignani, S. (2013), 'What is digital labour? What is digital work? What's their difference? And why do these questions matter for understanding social media?' TripleC: Communication, Capitalism \& Critique, 11 (2), 237-293.

Fumagalli, A. (2015), 'The concept of life subsumption of labour to capital: Towards the life subsumption in bio-cognitive capitalism', in E. Fisher and C. Fuchs (eds), Reconsidering Value and Labour in the Digital Age, London: Palgrave Macmillan, pp. 224-245.

Garegnani, P. (1979), Debate sobre la teoría marxista del valor, México: Pasado y Presente.

Graham, M. and Woodcock, J. (2018), 'Towards a fairer platform economy: Introducing the Fairwork Foundation', Alternate Routes: A Journal of Critical Social Research, 29. Retrieved from http://www.alternateroutes.ca/index.php/ar/article/view/22455

Hilferding, Rudolf ([1910] 1981), Finance Capital. A Study of the Latest Phase of Capitalist Development, edited by Tom Bottomore and translated by Morris Watnick and Sam Gordon, London: Routledge \& Kegan Paul.

Hodgson, G. (1988), 'Una teoria de la explotacion sin la teoria del valor-trabajo', Economía Teoría y Práctica, 12, 141-153.

Howcroft, D. and Bergvall-Kåreborn, B. (2018), 'A typology of crowdwork platforms', Work, Employment and Society, 33 (1). https://doi.org/10.1177/0950017018760136

Iñigo Carrera, J. (2003), El capital: razón histórica, sujeto revolucionario y conciencia, Buenos Aires: Ediciones cooperativas.

Langley, P. and Leyshon, A. (2017), 'Platform capitalism: The intermediation and capitalisation of digital economic circulation', Finance and Society, 3 (1), 11-31.

Lazzaratto, M. and Negri, A. (2001), Trabajo inmaterial. Formas de vida y producción de subjetividad, Río de Janeiro: DPA Editora.

Lund, A. and Zukerfeld, M. (2020), Corporate's Use of Openness: Profit for Free? London: Palgrave Macmillan.

Madariaga, J., Buenadicha, C., Molina, E. and Ernst, C. (2019), Economía de plataformas y empleo ¿Cómo es trabajar para una app en Argentina?, Buenos Aires: CIPPEC-BID-OIT.

Marx, Karl ([1867] 1990), The Process of Production of Capital. Vol 1 of Capital. A Critique of Political Economy, translated by Ben Fowkes, New York: Penguin.

May, C. and Sell, S. K. (2006), Intellectual Property Rights: A Critical History, Boulder, CO: Lynne Rienner Publishers. 
Omnicore (2019), 'YouTube by the numbers: Stats, demographics \& fun facts'. Available at https://www.omnicoreagency.com/youtube-statistics/

Piore, M. and Sabel, C. (1984), The Second Industrial Divide, New York: Basic Books.

Ricoeur, P. (2005), The Course of Recognition, London and Cambridge, MA: Harvard University Press.

Roemer, John E. (1985), 'Should Marxists be interested in exploitation?', Philosophy and Public Affairs, 14 (1) Winter, 30-65.

Rullani, E. (2000), 'El capitalismo cognitivo ¿un déjà- vu?', in E. Rodríguez and R. Sánchez (eds), Capitalismo cognitivo, propiedad intelectual y creación colectiva, Madrid: Traficantes de Sueños.

Schmidt, F. A. (2017), Digital Labour Markets in the Platform Economy: Mapping the Political Challenges of Crowd Work and Gig Work, Bonn: Friedrich-Ebert-Stiftung.

Scholz, T. (ed.) (2013), Digital Labor: The Internet as Playground and Factory, New York: Routledge.

Scholz, T. (2017), 'Platform cooperativism vs. the sharing economy', Big Data \& Civic Engagement, 47.

Simon, H. (1996), The Science of the Artificial, Cambridge, MA: The MIT Press.

Smythe, D (2006), 'On the audience commodity and its work', in M. Durham and D. Kellner (eds), Media and Cultural Studies, Malden, MA: Blackwell, pp. 230-256.

Srnicek, N. (2017), Platform Capitalism, Cambridge: Polity Press.

Standing, G. (2002), Beyond the New Paternalism: Basic Security as Equality, London: Verso.

Sweezy, Paul M. (1942), The Theory of Capitalist Development, New York: Monthly Review Press.

Vandaele, K. (2018), 'Will trade unions survive in the platform economy? Emerging patterns of platform workers' collective voice and representation in Europe (June 19, 2018)'. ETUI Research Paper. Working Paper 2018.05. Available at SSRN: https:// ssrn.com/abstract=3198546 or http://dx.doi.org/10.2139/ssrn.3198546

Varian, H. R. (1995), 'The information economy', Scientific American, 273 (3), 200-201.

Vercellone, C. (2011), Capitalismo cognitivo. Renta, saber y valor en la época posfordista, Buenos Aires: Prometeo.

Wright, E. O. (1985), Classes, London: Verso.

Zuboff, S. (2019), The Age of Surveillance Capitalism: The Fight for a Human Future at the New Frontier of Power, New York: PublicAffairs.

Zukerfeld, M. (2014), 'Inclusive appropriation and the double freedom of knowledge: On the capitalist exploitation of non-for-profit software, contents and data producers. Special Issue Free And Unpaid Work: Gratuity, Collaborative Activity And Precarioussnes', Sociología del Lavoro, 133, 144-158.

Zukerfeld, M. (2017), Knowledge in the Age of Digital Capitalism: An Introduction to Cognitive Materialism, London: University of Westminster Press.

Zukerfeld, M. (2017b), 'The tale of the snake and the elephant: Intellectual property expansion under informational capitalism', The Information Society, 33 (5), 243-260. DOI: 10.1080/01972243.2017.1354107. 